\title{
Farmer Community Emowerment in Indonesia
}

\author{
Ike Arni Noventi ${ }^{a} *$ \\ ${ }^{a}$ Brawijaya University, Malang, East Java, Indonesia
}

\section{INFORMASI ARTIKEL}

\section{Article history:}

Submission date: 14 Agustus 2017

First revision: 07 Juni 2017

Accepted: 14 Juni 2017

Available online: 28 November 2017

Keywords: empowerment, farmer community empowerment, agriculture development

\section{ABSTRACT}

Food sufficiency is closely related to a country's political stability. In order to achieve food sufficiency, local government need to conduct agriculture development which more focus on farmer community empowerment as main actor of ariculture development. This research aims to describe the efforts of local governmnet in empowering farmer community and analyze the appropriateness of those efforts with community empowerment concept. Descriptive research method with qualitative approach is used in this research. The result shows that local government has conducted farmer community empowerment efforts through several activities which are appropriate with the concept of community empowerment such as training, counseling, forming network, socialiszation, and providing loan. However, local government also gives subsidies and grant which are contrary to the concept of community empowerment and have potential to increase the dependence of the farmer on the local government.

\section{INTISARI}

Kecukupan pangan berkaitan erat dengan stabilitas politik suatu negara. Dalam rangka pemenuhan kebutuhan pangan, pemerintah daerah perlu melaksanakan pembangunan pertanian yang berfokus kepada pemberdayaan masyarakat petani sebagai pelaku utama pembangunan pertanian. Penelitian ini bertujuan untuk mendeskripsikan upaya-upaya pemerintah daerah dalam memberdayakan masyarakat petani serta menganalisa kesesuaian upaya tersebut dengan konsep pemberdayaan masyarakat. Metode penelitian deskriptif dengan pendekatan kualitataif digunakan pada penelitian ini. Hasil penelitian menunjukkan bahwa pemerintah daerah telah melakukan upaya-upaya pemberdayaan masyarakat petani yang sesuai dengan konsep pemberdayaan masyarakat melalui pelaksanaan kegiatan pelatihan, penyuluhan, pembentukan jaringan kerja, sosialisasi, dan penyediaan pinjaman. Namun pemerintah daerah juga memberikan subsidi dan hibah yang bertentangan dengan konsep pemberdayaan masyarakat dan berpotensi meningkatkan ketergantungan masyarakat petani terhadap pemerintah daerah

2017 FIA UB. All rights reserved.

\section{Introduction}

Food is a principal needs in human life. Food has a big role in ensuring the continuity of human life in the world. Governmnet has a big role and responsibility in food fulfillment for everyone withis its territorial area.
Furthermore, food sufficiency is closely related to a country's political stability. Political unstability could be caused by food insufficiency, on the contrary, food insufficiency could also be caused by political unstability (Maxwell, 2012).

\footnotetext{
* Corresponding author. Tel.: +628113042499; e-mail: ike_arni_noventi@yahoo.com
} 
Agriculture sector is one of development sector wich plays main role in food sufficiency. Agriculture development should be prioritized in order to achieve optimal food sufficiency. Agriculture development has objectives to fulfill human necessities and achieve welfare by increasing food productivity and using resources efficiently. Government in every countries has attempted through many methods in order to fulfill food necessities of their citizen. In Indonesia, the government implemented Green Revolution in 1970s through Panca Usaha Pertanian by founding chemical fertilizer and pesticide industries, agricultural tools production, using superior variety of paddy called International Rice (IR), and also giving credit supply to farmer. Based on the history of green revolution, it can be defined generally that green revolution is a modern agriculture development policy to answer food requirement and improving food production by synthetic fertilizers and the other chemical elements (Widiarta, et al., 2009).

Through a program that is introduced by William Gaud in 1968, a former USAID director and supported by the Ford Foundation and the Rockefeller Foundation, Indonesia was succeeded in running this program and has brought Indonesia to an improvement of food agricultural productivity. In 1984 Indonesia was considered as a food self-sufficiency country. The Green Revolution brought Indonesia into big changes, included farmer characteristics that moved from anti-technology to used-technology. However, in Indonesia, the green revolution also brought negative impacts such as environmental degradation and dependency of the farmer toward the government for further agricultural development (Widiarta, et al., 2009). The approach that was brought by the Green Revolution by emphasizing more on transfer of technology, not on transfer of knowledge and learning process has decreased farmer's creativity and increased the farmer's dependence on government, espescially local government (Chambers, 1993 in Sadono, 2008). This dependency espescially in terms of chemical fertilizer and pesticide (Saragih, 2009).

Farmer dependency is a big problem that needs serious treatment and solution. Farmer is a main subject and actor in the field of agriculture. Without farmer, agriculture development has no meaning. Therefore, agriculture development in Indonesia should more focus on farmer community empowerment with the result that the farmer could be more creative, independent, and competitive. Empowering farmer community is the most important thing that will increase the capacity and capability of farmer community as the main actor in development of agriculture sector. By increasing their capacity and capability, the farmers are able to manage their farm land properly and increase the agriculture production that automatically also increase social welfare of the farmer.

Empowerment could broadly defines as activities which are able to increase the people abilities and make them strong enough to participate in a variety of control over, and the influence of events and institutions that affect their lives by emphasizing on the acquiring of skills, knowledge, and power which is quite affecting their life and the others who become their concern (Parson, et al, 1994 in Suharto, 1997). Furthermore, empowerment is a gradual process that should be conducted in order to get and increase capability to be more independent (Sulistyani, 2004). Related to development practice, one of new economic growth theories argues that investment in human resources through education and training and improving health status have a major impact on improving productivity (Becker, 1964 in Xiao, 2001:1-2). Therefore, empowerment is one of the most important factors that influence the success of development.

Considering the importance of farmer community empowerment toward agriculture development and achieving food sufficiency, the government, espescially local governmnet that has direct contact to farmer community has responsibility to empowering this community. Logal government in Indonesia espescially which has wide agriculture area and most of its population has livelihood in agriculture sector should conduct various efforts in empowering farmer community.

Local government of Malang Regency with its area approximately $3.347,8 \mathrm{~km} 2$ and is ranked as the second largest of 38 regencies and municipalities in East Java Province has agriculture land approximately 75 percent of its total area. This geographical condition is strongly related to the society's occupation where from the total population over the age of 10 years old which is in the amount of 1.407 .686 people, 511.966 people or about 36,37 percent work in agriculture sector (Local Government of Malang Regency, 2010). Considering this condition, the locl government should conduct various efforts to empower farmer community. The most important thing is those efforts should lead to the increasing of farmer crativity and independence which in turn could remove the farmer's dependency on the local government.

\section{Theory}

\subsection{Empowerment}

Many definitions of empowerment proposed by experts. Some experts suggest that the definition of empowerment can be seen from the objectives, process, and ways of empowerment as follows (Suharto, 1997): 
a. Empowerment aims to increase the power of people who are weak or unlucky (Ife, 1995).

b. Empowerment is a process by which people become strong enough to participate in a variety of control over, and the influence of events and institutions that affect their lives. It emphasizes that people acquire skills, knowledge, and power which is quite affecting their lives and the lives of others who become their concern (Parson, et al, 1994).

c. Empowerment refers to the efforts of re-allocation power in a changing social structure (Swift and Levin, 1987).

d. Empowerment is a way with the name of people, organizations, and community directed to be able to control or power over life (Rappaport, 1984).

In addition, Ambar Teguh Sulistyani (2004) mentions there are two specials points derived from the meaning of empowerment, namely:

a. Power is understood as a capability that should be owned by the public so they can do something (development) independently;

b. While empowerment is a gradual process that must be done in order to acquire and improve capability so that communities are able to be independent.

From those two special points can be concluded that empowerment should not contain people into the trap of dependency (charity), but should deliver the community to the process or stage of independence.

Empowerment is a process of learning that will be occured gradually and passes these phases:

a. Phase of awareness, it is a people behavior where they feel that they need to increase their self-capacity.

b. Phase transformation, it is related to knowledge, proficiency skills for the future and provide basic skills so that they can take a role in the development.

c. Phase improving intellectual ability, skill proficiency, forming the initiative and innovative ability to deliver on independence (Sulistyani, 2007:83).

\subsection{Community Empowrment}

Community empowerment is one of the important strategy in a development (Usman, 2004 in Mangowal, 2013). Community empowerment has important meaning in creating and increaing the independence so the community could act, understand, and apply their power in various development activities (Mangowal, 2013). The concept of community empowerment could has meaning in the context of "stand up" community. This concept put the community not as an object who receive benefits (beneficiaries) that dependence on the other party (government), but as a subject (agen or participant) who doing someting independently. It means that the space and capacity to increase their potential and creativity, control the environment and their own resources, overcome the problems, even take a part in determining political process at national level is wide-open. Therefore, the community could participate in the process of government and development (Eko, 2002).

Furthermore, Randy R. Wrihatnolo, et al. (2007) explain the sense of community empowerment as elements that allow people to survive dynamically in the sense of personal development and achieve progress. Empowerment is a source of insight into what is in politics at the national level called national defense. While, empowering communities is an effort to enhance the dignity of Indonesian society that is not able to escape from the poverty trap. In other words, is to enable and to make the people independent.

\subsection{Farmer Community Empowerment}

Farmer community empowerment is a concept of community empowerment espescially for farmer community as main actor driving agriculture sector. It is an effort to increase the indepenent attitude in running agriculture business. It emphasizes on informal eductaion and a continuous and comprehensive counseling in order to increase farmer's knowledge and perception related to agriculture sector, this is an alternative of attitude development (Manowal, 2013).

The effort in increasing the farmer's power is conducted through increasing human resource quality of the farmers by facilitating agriculture business through givig formal and informal eduction related to agriculture (Zahriyani, 2009). Basically, farmer community empowerment concept means putting farmer community with its institutions as basic power for economic, social, and cultural development (Mangowal, 2013).

\section{Research Method}

This research is descriptive research with qualitative approach. Qualitative method is research procedures which produce descriptive data in the form of words or oral of people and behaviors that can be observed. The descriptive research method with qualitative approach is a research process that aims to describe the exact nature / something was happening and took place on the research conducted (Moleong, 2000). With qualitative data, the researchers can follow and understand the flow of events in chronological order, assess the cause and effect within the scope of the local people's minds, and again, the qualitative data is more likely to be guiding us to obtain discoveries unforeseen and to form a new theoretical framework of data. It helps the researchers to go beyond the initial preconceptions and frameworks (Miles, 1992). 
This research focuses on farmer community empowerment, espescially the efforts conducted by Local Government of Malang Regency in empowering farmer community and its appropriateness with the community empowerment concept. Data collection is conducted by obersing and interviewing civil servant form 5 (five) departments which has main responsibility in developing agriculture sector. Data analysis in this research is interactive analysis model from Miles Huberman and Saldana (2014) that consists of data collection, data presentation, drawing conclusion and verification, and data condentation.

\section{Results and Discussion}

\subsection{Related Departments in Empowering Farmer Community}

Local government of Maang Regency in its Document of Gross Regional Domestic Product of 2010 has defined the scope of agriculture based on local government of Malang Regency is consist of crop and plantation, forestry, animal husbandry, and fishery. Taking a consideration to the scope of agriculture itself and also to the governmental structure of Malang Regency, it can be concluded that there are at least 4 main local governmental working units that has main responsibility to develop agriculture sector in this regency, namely Department of Agriculture and Plantation, Department of Animal Husbandry and Health, Department of Forestry, and Department of Marine and Fishery. Those departments have agriculture development programs that formulated and conducted annualy. However, for conducting farmer empowerment programs, those departments should collaborate wih Food Security and Counseling Implementer Agency. This agency is a special agency where the counselors from those departments are grouped and has main responsibility in empowering farmer community and also has its own farmer community empowerment programs. Formerly, each departments has their own counselors.

However, the separation of those councelors from those departments and grouping them in a separated agency causes a problem in farmer community empowerment. Most of farmer community empowerment programs are conducted very late because of long process of coordinatioan among departments and agency. The limited number of counselor is also still become a problem. The number of counselors is too limited comparing with the number of farmer community. In addition, the very wide work coverage area of each counselors makes them need extra time and energy to reach the farmer community. This condition makes the implmenetation of farmer community empowerment programs innefective.

\subsection{Farmer Community Empowerment Conducted by Local Government}

In order to optimize agriculture development in its territorial area, Local Government of Malang Regency has conducted various efforts in empowering farmer community which is stated in annual working programs of each related departments and agency. Farmer community empowerment programs are part of agriculture development programs belong to all related department and agency. This is because farmer community empowerment could not be separated from agriculture development since the farmer is the main actor in agricuture sector. Farmer community empowerment is agriculture development in the terms of agriculture human resources. However, farmer community empowermment programs still have little portion. From 44 (fourty four) programs of agriculture development conducted by the local government within a year, there are only 15 (fifteen) programs of farmer community empowerment or about 34,09 percent.

Farmer community empowerment programs are implemented through various activities. Those activities involves not only farmer community and government, but also the other parties related to farmer community empowerment such as farmer famili and private sector. The local governmnet also create collaboration with some related parties in order to be able to conduct farmer community empowerment programs properly. Farmer community empowerment programs conducted by local government could be broadly classified into 5 (five) activities, namely training, counseling, forming network, socialiszation, and providing loan, also giving subsidies and grant.

\subsubsection{Training}

Training is the main activity in empowering people and could not be separated from empowerment activities. In empowering farmer community, training is also an important activity. Training aims to increase knowledge and skill the target (people, group or organization) concerning a certain matter. The increasing knowledge and skill is expected could transform the target to be more creative and independent, so they are not dependent on other parties anymore, espescially the local government. In order to empowering farmer community within its territorial area, Local Government of Malang Regency through its related departents and agency conducted various farmer community empowerment. In practice, this activities involve the farmer and the counselors.

The counselors delivers various topics related to agriculture development, concerning not only increasing agriculture productivity, but also agriculture product processing in order to increase its economic value and 
help to fulfill food necessity during cultivating season. In addition, there are other kind of training such as formation and management of agriculture business, organic fertilizer processing, and agriculture waste processing. Some examples of training activities conducted by this local government are training in applying agriculture technology, training on formation agriculture business network, training on milk and meat processing, also training on compost fertilizer processing.

\subsubsection{Counseling}

In order to empowering farmer community in Malang Regency, the local government conducted counseling activities. In practice, this activity counducted by the counselors toward farmer community espescialy who involves in farmer groups. This activity aims to give guidance concerning various matter related to agriculture development espescially how to develop agriculture business properly. Conseling activity also become a medium of consultation between farmers and counselors in terms of development and management of agriculture business. Through this activity, the farmers are expected to be able to solve their problems by themselves properly.

Counseling activity conducted by the local government covers many topic such as institutional strengthening of farmer group, developing agriculture business, increasing agriculture productivity, also agricultur product processing. Practically, counseling activities that has been conducted by the local governmnet are selection and development of forage seed, processing fish, development of aquaculture business, also establishment of farmer cooperative.

\subsubsection{Forming Network}

Network is one of the most important factors that determines the success of agriculture development and farmer community empowerment. In order to empoering farmer community, network needs to be created to get various input which could provide easy of developing agriculture business for the farmer community. Actors within this network could work together and create collaboration to create mutualism network. For an example, in the terms of agriculture product marketing and getting capital assistance, farmer community should make a collaboration with private sector so they could get previledge and easy access in marketing of agriculture product and accessing loan for their business.

Considering the importance of network, the local government create network that involves not only farmer community and the locla government, but also private sector espescially bank. Private sectors are expected to be able to provide easy access in providing loan for the farmer community so they could develop their business. Through this network the farmer could get the loan easily by showng the recomendation letter from the related departments. In additition, the farmers also get the loan with low interest because of this network.

\subsubsection{Socialiszation}

Besides through training and counseling activities, socialiszation activity is also conducted in order to empower the farmer community. This activity aims to increase the understanding of farmers, even including their family concerning agriculture development. In addition, socialiszation activities are expected to be able to increase awareness, change the mindset and habit the farmers and the people around them. In some socialiszation activities, there is demonstration activity related to introduction of a new agricultural method.

\subsubsection{Providing Loan}

In order to increase the indepencence of the farmers, capital in proper amount is needed to develop agriculture business of the farmer. The local government attempt to provide fund for the farmers through giving loan. However, the locla government could not provide the loan in a big amount by itself. Therefore, the local government make a collaboration with the banks to provide fund for the marmers.

The loan could be proposed by the farmers to the banks after giving report and get the recommendation letter from related departments. The related department would select the proposal from the farmers and ensure that the loan which is proposed is for developing agriculture business. The recomendation letter from the related department is used to proposed the loan to the bank and also help the farmers to get the low interest.

Besides those five activities, the local government often gives subsidies and grant together with the implemnetation of those five kinds of empowerment activities. The kind of subsidies and grant is related to the development of agriculture business running by farmer community. For grant, usually the local government give it together with the implementation of training, counseling, and socialiszation activities. For example, when the training of increasing agriculture productivity, the local government gives plantation seeds, agriculture tools such as cassava seeds, maize seeds, and paddy mower.

While for subsidies, the local government gives subsdies to the farmers such as fertilizer, pesticide, and seeds so the farmer could get those with th elow price. The local government also gives subsidy to decrease the loan interest which sould be paid by the farmers. Through this kind of subsidy, the farmer could get the 
loan wth low amount of interest for developing their agriculture business.

\subsection{The Appropriateness of Farmer Community Empowerment Efforts with Community Empowerment Concept}

Empowerment concept as one of development strategy has several important points as follows:

a) the existence of gradual process in increasing capability of the unlucky or powerless people or group of people through transfer of knowledge dan skill;

b) aims to increase creativity and independence;

c) breaking the dependence on other parties.

In line to those points, the farmer community empowerment also aims to increase farmer's capability, creativity, and independence. In addition, this kind of empowerment also aims to break the dependence of the farmers on other parties espescially the local government.

Farmer community empowerment as a strategy in developing agriculture sectorneeds to be conducted in order to increase the farmer's independence that has been decreased drastically since the implementation of Green Revolution that caused high dependency of the farmers of the local government's assisstance in terms of fertilizer, pesticide, and agriculture tools. Whereas the farmers as the main actor in agriculture development should play role as subject who could act independently, not as beneficiaries who dependent on other parties's subsidies and grant. Therefore, farmer community empowerment programs plays a big role in delivering the farmers to achieve independence and break out the dependency chain between the farmers and the local government through transfer and aqcuisition of knowledge and skill. The efforts of local government in empowering farmer community should more focus on increasing the farmer's capability and capacity

Activities of empowering farmer community conducted by the local government such as training, counseling, socialiszation, network formation, and providing loan are appropriate with the concept of community empowerment which prioritized the increasing capacity and cpability of the farmers. For providing loan activity, this kind of activitiy play role in increasing farmer's independence and responsibility becuse they must pay back the loan based on the provisions by bank and agreed by the farmers as debitur. While the activity of giving subsidy and grant that is implemented together with the other farmer community empowerment is not relevant at all with the concept of farmer community empowerment. Giving grant to the farmer while the local government conducted the training, counseling, and socializsation activities has potential to shift the farmer's focus from getting knowledge and skill that have a huge benefit for increasing their independence and capability wich in turn could developing their agriculture business to getting grant only. This could lead the farmer have no willing to get new knowledge, skill, and experience. The grant might be better give to the farmer through competetion mechanism related to farmer's creativity and innovation in developing agriculture sector.

Giving subsidies and grant, besides not relevant with the concept of community empowerent, those two kind activities have also a big potential in increasing farmer's dependency on the local government. Although giving subsidies and grant has a potential to increase the agriculture productivity, it would be only for a short term. Furthermore, subsidies and grant in turn could increase the annual expenditure of the local government. Therefore, the local government should has removed giving subsidies and grant to the farmers from their farmer community empowerment programs.

\section{Conclusion}

Farmer community empowerment in Local Goverment of Malang Regency is conducted by the local government through related departments and agency in order to increase the farmer community's independence and creativity through many empowerment programs. Those related departments and agency are Department of Agriculture and Plantation, Department of Animal Husbandry and Health, Department of Forestry, and Department of Marine and Fishery, also Food Security and Counseling Implementer Agency. Farmer community empowerment is a part of agriculture development which focuses on human resource development of the farmer which is arranged and implemented annualy by all related departments and agency.

Farmer community empowerment programs are conducted by the local government through the implementation of many kinds activities that could be classified into five kinds of activity namely trainng, counseling, network formation, providing loan, and socialiszation. Those kinds of activity are appropriate with the concept of community empowerment. However in practice, there is still activity of giving grant and subsidies that againts the community empowerment concept which in turn could increase the dependency of the farmer on the local government and also increase the local government expenditure.

\section{Bibliography}

Eko, Sutoro. (2002). Pemberdayaan Masyarakat Desa. Samarinda: Badan Diklat Provinsi Kaltim. 
Local Government of Malang Regency. (2010). Human Development Index 2011. Malang: Local Government of Malang Regency.

Mangowal, Jack. (2013). Pemberdayaan Masyarakat Petani dalam Meningkatkan Pengembangan Ekonomi Pedesaan di Desa Tumani Kecamatan Maesan kabupaten Minahasa Selatan. Available at: https://www.google.co.id/url?sa=t\&rct= j\&q = $\&$ esrc $=$ s\&source $=$ web $\& c d=2 \& c a d=r j a \& u a c t=8 \&$ ved=0ahUKEwi2gcWG75vXAhXJH5QKHY6m DBEQFggwMAE\&url=https\%3A\%2F\%2Fejourn al.unsrat.ac.id\%2Findex.php $\% 2$ Fgovernance $\% 2 \mathrm{~F}$ article $\% 2$ FviewFile $\% 2 \mathrm{~F} 1481 \% 2 \mathrm{~F} 1179 \&$ usg $=\mathrm{AO}$ vVaw2GoQ1p8dGRXppnx2_-kYin.

$[\mathrm{Be}$ Accessed on October $\left.9^{\text {th }}, 2017\right]$.

Maxwell, Daniel. (2012). Food Security and Its Implications for Political Stability: A Humanitarian Persective. Available at: https://www.google.co.id/url?sa=t\&rct=j\&q=\&esr $\mathrm{c}=\mathrm{s} \&$ source $=$ web $\& \mathrm{~cd}=2 \& \mathrm{cad}=\mathrm{rja} \&$ uact $=8 \& \mathrm{ved}=$ 0ahUKEwihr-S92vHWAhUMMI8 KHX2EAF0Q Fgg_MAE\&url=http\%3A\%2F\%2Fwww.fao.org $\%$ 2Ffileadmin\%2Ftemplates\%2Fcfs_high_level_f orum $\% 2$ Fdocuments $\% 2$ FFS-Implications Political_Stability-Maxwell. pdf\&usg= Aov Vaw 0Z2C2UH5tyeW1K_aeEgw6g. [Be Accessed on October $\left.9^{\text {th }}, 2017\right]$.

Miles, B. Huberman. (1992). Analisa Data Kualitatif. Jakarta: UI Pers.

Miles, Mathew B., Michael Huberman, \& Johnny Saldana. (2014). Qualitative Data Analysis: A Methods Sourcebook. London: Sage Publication Ltd.

Moleong, Lexy J. (2000). Metode Penelitian Kualitatif. Bandung: Rosda Karya.

Sadono, Dwi. (2008). Pemberdayaan Petani: Paradigma Baru Penyuluhan Pertanian di Indonesia. Jurnal Penyuluhan Vol. 4 No. 1 : 65-74. Available at: http://repository.ipb.ac.id/jspui/bitstream/1234567 89/43076/1/Dwi\%20Sadono.pdf. [Be Accessed on October $\left.9^{\text {th }}, 2017\right]$.

Saragih, Henry. (2009). Pandangan Petani atas Kebijakan Pertanian Pemerintah Tahun 2008. Available at: https://www.google. co.id/url? $\mathrm{sa}=\mathrm{t} \& \mathrm{rct}=\quad \mathrm{j} \& \mathrm{q}=\&$ esrc $=\mathrm{s} \&$ source $=\quad$ web\&cd $=7 \& \mathrm{cad}=$ rja\&uact $=8 \& \mathrm{ved}=0 \mathrm{ahUKEwjLoIPvloD}$ XAhWJpY8KHb6oDrUQFghOMAY\&url=https $\% 3 \mathrm{~A} \% 2 \mathrm{~F} \% 2 \mathrm{Fwww}$.spi.or.id\%2Fwp-content $\% 2$ Fuploads\%2F2008\%2F01\%2Fpandangan_petani_ 2008.pdf\&usg=AOvVaw06Nk3zhM7Jdm18gIZy ZS1Q. [Be Accessed on October $\left.9^{\text {th }}, 2017\right]$.

Suharto, Edi. (2009). Membangun Masyarakat, Memberdayakan Masyarakat. Malang : Refika Aditama Unmuh.
Sulistiyani, Ambar Teguh. 2007. Kemitraan dan ModelModel Pemberdayaan. Yogyakarta: Gaya Media.

Widiarta, Aero; Isma Rosyida; Rajib Gandi; Hukmayra Secelia Muswar. (2009). Peasant Empowerment Through Social Capital Reinforcement: Road to Sustainable Organic Agriculture Development. Assian Journal of Food and Agro-Industry S297S306.

Wrihatnolo, Randy R. (2007). Manajemen Pemberdayaan: Sebuah Pengantar dan Panduan untuk Pemberdayaan Masyarakat. Jakarta: PT. Alex Mudia Komputindo.

Xiao, Jian. (2001). Determinants of Salary Growth in Shenzhen, China: An Analysis of Formal Education, On-the-jobtraining and Adult Education with A Three Level Model. Available at: www.t.ccolumbia.edu/counters/coce/pdf_files //d4.pdf. [Be accessed on March 14 $\left.{ }^{\text {th }}, 2012\right]$.

Zahriyani, P. (2009). Pembangunan Pertanian di Era Globalisasi. Jakarta: PT Pelita Harapan. 